\title{
ANALISIS BIAYA PROJEK KONSTRUKSI DI INDONESIA DALAM PERSPEKTIF SYARIAH
}

\author{
Agung Sedayu
}

Jurusan Teknik Arsitektur, Fakultas Sains dan Teknologi,

UIN Maulana Malik Ibrahim Malang, Indonesia

e-mail: agung_resta@yahoo.co.id

\begin{abstract}
The monetary circulation in construction projects is very important to be analyse and evaluated from the perspective of islamic law. This is so because most construction companies were indicated practicing some methods which have no basis in Islam. Some of them are even legally done some practice which considered as forbidden in Islam, such as dishonesty, manipulations, and injustice acts. Moreover, in Indonesia most of construction companies are using a foreign method from the former collonial government. The methods are found to be generating conflicts between persons in the project, and therefore could damage the social relationship of human being. BOW Analysis, and SNI which developed from BOW are still used in Indonesia. Those methods are not able yet to stand for some essential human rights, especially for the projects' labor. The same condition happens too in the modern-world analysis which have coeffecients in determining worker fee, such as Weibull Analysis. This very sophisticated analysis is unable to answer the economic problems of society. All these methods were developed under the capitalistic framework which only intended to obtain more individual benefit, without considering the loss resulted to other people's lives. Labor's payment is very low in this capitalistic construction analysis. They are assumed similar to machines and equipments which has a range of productivity. If they became unproductive after some period of time, they can be thrown easily without considering their lives needs. On the other side, economic system in Islamic law is provided with some solutions to answer all social and economical problems in the society. Shariah economic and management system which is applied in a construction corporation's system analysis and accountancy will bring great advantages, whether for its labor and company, or for society in general. Within the shariah construction management, all parties will reach Allah's blessing and gain benefits in both worldly life and the hereafter.
\end{abstract}

Keywords: Shariah management, cost analysing, construction project

\begin{abstract}
Abstrak
Laju perputaran uang di dalam suatu projek konstruksi sangat penting untuk dikaji, apalagi dalam perspektif syariah islam. Selama ini, sebagian besar perusahaan konstruksi telah menerapkan metode-metode yang terindikasi tidak sesuai dengan nilai-nilai Islam. Di Indonesia, sebagian besar perusahaan konstruksi menggunakan metode yang merupakan warisan dari pemerintah kolonial Belanda. Metode-metode lain yang ada pun banyak menimbulkan konflik di antara pihak-pihak yang terlibat di dalamnya, sehingga membawa dampak kerusakan hubungan sosial. Analisis BOW, dan SNI yang merupakan pengembangan dari BOW masih banyak diterapkan di Indonesia. Metode-metode tersebut masih belum mampu mengangkat harkat martabat manusia, terutama buruh pekerja. Begitu juga dengan analisis modern yang sangat kikir dengan koefesien-koefesiennya dalam menentukan upah pekerja. Bahkan Analisis Weibull yang sangat canggih sekalipun tidak mampu menjawab persoalan ekonomi masyarakat. Hal ini dikarenakan metode-metode tersebut dikembangkan berdasarkan paham kapitalistik yang hanya bertujuan untuk mendapatkan keuntungan pribadi semata, tanpa mempertimbangkan kehidupan orang lain dan kerugian yang diakibatkannya. Nilai pekerja sangat rendah di mata analisis konstruksi kapitalistik ini. Para pekerja dianggap hanya setara dengan mesin dan peralatan yang apabila tidak produktif dapat dibuang dengan mudah. Sistem ekonomi dan manajemen syariah merupakan solusi untuk menyelesaikan segala kesulitan dan permasalahan ekonomi yang melanda masyarakat. Penerapan sistem ekonomi dan manajemen syariah di suatu korporasi konstruksi dengan sistem analisis dan akuntansinya akan mengantarkan para pelakunya kepada ridha Allah swt dan meraih keselamatan dunia akhirat.
\end{abstract}

Kata kunci: Projek konstruksi, manajemen syariah, analisis biaya

\section{Pendahuluan: Perkembangan Projek Konstruksi di Indonesia}

Projek konstruksi di Indonesia mengalami pasang surut yang beragam. Pada masa Orde Baru, terjadi peningkatan yang signifikan dari projek konstruksi, karena pemerintah pada masa itu sangat menekankan pentingnya pembangunan fisik sebagai simbol dari pembangunan bangsa secara keseluruhan. Ketika Orde Baru runtuh, yang ditandai dengan krisis ekonomi, terjadi penurunan volume pembangunan fisik yang diakibatkan oleh adanya kelesuan bisnis konstruksi di Indonesia. 
Lesunya projek konstruksi tidak berlangsung lama, karena pada awal abad ke-21 semangat untuk membangun berbagai fasilitas dan gedung-gedung bertingkat kembali bangkit dan maju pesat hingga saat ini. Tumbuh kembangnya projek konstruksi pada dekade ini ditandai dengan munculnya perusahaanperusahaan konstruksi, baik level menengah maupun level bawah, sedangkan untuk level atas tidak terjadi banyak perubahan. Terdapat banyak pula inovasi dan terobosan yang dilakukan para praktisi dan pengusaha konstruksi dalam mengelola organisasinya, mulai manajerial kantor, hubungan masyarakat, pemasaran, hingga pelaksanaan dan implementasi fisik di lapangan. Seluruh korporasi konstruksi semakin berpacu dengan segala strategi dan metode yang mereka kerahkan agar perusahaan mereka tetap eksis dan tidak kalah bersaing dengan korporasi lain. Tidak jarang pula korporasi konstruksi ini melakukan upaya-upaya untuk meningkatkan kinerja pengelolaan projeknya.

Terdapat cukup banyak metode dan model manajemen projek yang diterapkan di dunia konstruksi, termasuk analisis dan pembukuan projeknya. Sistem manajemen tersebut sebagian besar diadopsi dari teori-teori di negara Barat, misalnya dalam analisis biaya menggunakan sistem SNI yang merupakan perkembangan dari analisis BOW yang diciptakan oleh kolonial Belanda pada masa penjajahan di tanah air.

Dari sekian banyak metode analisis biaya yang diterapkan di banyak negara, terdapat banyak metode yang menimbulkan kerugian bagi pihak lain atau memunculkan konflik sosial. Di lain pihak, Islam sebagai agama yang menjiwai seluruh aspek kehidupan, ternyata memiliki prinsip-prinsip manajemen dan analisis biaya yang sesuai syariah Islam. Penerapan manajemen syariah Islam secara global dapat mengarahkan para pelaku projek untuk menghindari kerusakan dan meraih kemaslahatan bagi seluruh pihak, baik di dunia maupun di akhirat.

\section{Analisis Biaya dan Akuntansi Syariah}

Iman Soeharto menjelaskan konsep perkiraan biaya sebagai sebuah seni memperkirakan (the art of approximating) kemungkinan jumlah biaya yang diperlukan untuk suatu kegiatan yang didasarkan pada informasi yang tersedia waktu itu. Sementara itu, cost engineering adalah bidang kegiatan engineering dimana pengalaman dan pertimbangan engineering dipakai pada aplikasi prinsip-prinsip teknik dan ilmu pengetahuan dalam masalah perkiraan biaya, pengendalian biaya, dan profitabilitas ${ }^{1}$.

Sebelum projek konstruksi dijalankan maka diperlukan perencanaan dalam bidang pembiayaan, termasuk analisis dan akuntansi biaya. Tahapan perencanaan ini harus disiapkan dengan matang dan baik, sebagaimana hadits riwayat Ibnul Mubarak berikut:

"Jika engkau ingin mengerjakan sesuatu pekerjaan, maka pikirkanlah akibatnya, maka jika perbuatan itu baik ambillah dan jika perbuatan itu jelek, maka tinggalkanlah."

Ali Bin Abi Thalib ra. juga pernah berkata sebagai berikut:

"Hak atau kebenaran yang tidak terorganisir dengan rapi, bisa dikalahkan oleh kebatilan yang lebih terorganisir dengan rapi. "3

Asal mula akuntansi pertama kali ditemukan oleh Lucas Pacioli di Italia pada tahun 1494 yang dikenal dengan pembukuan berpasangan (double entry book keeping) yang sekarang dipakai kalangan akademisi, perusahaan, dan pekerja akuntansi ${ }^{4}$. Shehata mengatakan bahwa sebenarnya pembukuan berpasangan sudah lama muncul sejak peradaban Islam dan sudah dipraktekkan pada masa Rasulullah saw. Walaupun demikian, karena keterbatasan materi dan bahasa pada masa itu, kitab-kitab yang mengatur tentang pembukuan hanya berupa manuskrip saja. Hal itu bisa dibuktikan dengan adanya manuskrip karya penulis muslim, Abdullah bin Muhammad bin Kayah al-Mazindarani, di dalam kitab "Risalah Falakiyah Kitab As Siyakat" pada tahun $765 \mathrm{H} / 1363 \mathrm{M}$ atau 131 tahun sebelum munculnya buku Pacioli. Menurut al-Mazindarani, sistem-sistem yang popular pada saat itu antara lain adalah akuntansi bangunan, akuntansi pertanian, akuntansi pergudangan, akuntansi pembuatan uang, dan akuntansi pemeliharaan binatang.

Di antara contoh pelaksanaan pembukuan yang disebutkan oleh al-Mazindarani di masa itu, bahwa penyusunan laporan atau pencatatan di buku-buku akuntansi harus dimulai dengan basmalah ${ }^{5}$. Setelah itu, 131 tahun kemudian penulis Italia Pacioli juga menyebut yang sama seraya berkata, "Harus dimulai dengan ungkapan Bismillah." Hal ini menunjukkan bahwa terdapat kesadaran untuk selalu menyertakan Allah di dalam setiap kegiatan ekonomi dengan cara memperhatikan aturan-aturan yang ada di dalam Islam mengenai niat, akad, transaksi, dan sebagainya.

Dalam projek konstruksi, owner (konsumen) membutuhkan jasa pelaksana (kontraktor) untuk mendirikan bangunan, dengan cara pihak owner membayar sejumlah uang kepada pelaksana. Dengan demikian, terdapat interaksi yang sangat erat di antara keduanya yang harus dijaga sebaik mungkin agar tidak menimbulkan konflik. Dalam manajemen syariah sendiri, pihak pelaksana wajib memberikan informasi yang benar, jelas, dan jujur mengenai barang atau jasa, serta memberikan penjelasan mengenai penggunaan, perbaikan, dan pemeliharaan serta wajib menjamin mutu barang atau jasa yang 
dihasilkan berdasarkan ketentuan standar yang berlaku mengenai mutu barang atau jasa ${ }^{6}$.

Menyangkut penentuan upah kerja, syariat Islam tidak memberikan ketentuan yang rinci secara tekstual, baik di dalam al-Quran maupun al-Hadits. Secara umum, ketentuan al-Quran yang berkaitan dengan penentuan upah kerja, menurut Suhrawardi K. Lubis $^{7}$ adalah sebagai berikut:

"Allah memerintahkan berbuat adil, melakukan kebaikan, dan dermawan terhadap kerabat. la melarang berbuat keji, kemungkaran, dan penindasan. la mengingatkan kamu supaya mengambil pelajaran"8

Untuk menentukan upah kerja, menurut Ahmad Azhar Basyir', setidaknya kita dapat berpedoman pada Sunnah Rasulullah diriwayatkan Bukhari dan Muslim, sebagai berikut:

"Bahwa ajir khash pembantu rumah tangga, hendaklah dipandang sebagai keluarga sendiri yang kebetulan berada di bawah kekuasaan kepala rumah tangga. Pembantu rumah tangga yang berada di bawah kekuasaan kepala rumah tangga hendaklah diberi makan seperti yang dimakan oleh keluarga rumah tangganya, diberi pakaian seperti yang dipakai keluarga rumah tangganya, jangan diberi pekerjaan di luar kekuatan yang wajar. Jika dibebani pekerjaan hendaklah dibantu untuk meringankan."

Di dalam hadits riwayat Ibnu Majjah Nabi bersabda, sebagai berikut:

"Berilah olehmu upah orang pekerja sebelum keringatnya kering."

Selain itu, di dalam hadits Rasulullah saw yang diriwayatkan oleh Abdullah, dikemukakan pula sebagai berikut:

"Berusahalah untuk memperoleh kehidupan dengan cara yang halal, merupakan suatu kewajiban sesudah kewajiban sembahyang". ${ }^{10}$

\section{Analisis Integrasi Menurut Abudayyah}

OY. Abudayyah, merupakan seorang pakar analisis biaya konstruksi muslim berkebangsaan Amerika, pada tahun 1991 mengemukakan konsep analisis biaya dan akuntansi projek yang mengintegrasikan biaya, jadwal, dan kualitas projek berlandaskan konstruksi syariah ${ }^{11}$. Para pelaku projek merupakan faktor terpenting yang menentukan berhasil tidaknya projek. Oleh sebab itu, para pelaku projek mulai tingkat atas hingga bawah sekalipun dimasukkan ke dalam satu organisasi yang solid yang bekerja bersama-sama atau berjamaah. Organisasi tersebut dibagi lagi ke dalam beberapa divisi sesuai dengan ruang lingkup tugas dan pekerjaan masing-masing. Dalam analisis biaya, tiga variabel dijadikan satu kesatuan dalam melakukan pengukuran. Ketiga unsur tersebut berbanding linier satu dengan yang lain, pengukuran progres jadwal projek dapat diukur dengan biaya yang dikeluarkan dan kualitas implementasi fisik $^{12}$. Buruh dan tenaga kerja mendapat proporsi yang baik dan dihargai, karena analisis biaya juga didukung oleh pengukuran beban kerja dan deskripsi tugas yang dikerjakan. Buruh dan tenaga kerja dapat melakukan kontrol terhadap akurasi pengukuran kemajuan projek. Produk yang dihasilkan adalah hak bagi konsumen atau klien. Setiap pekerjaan merupakan media ibadah yang menunjukkan keterikatan hubungan manusia dengan Allah, manusia lain, dan lingkungan sekitarnya. Konsep analisis yang dikemukakan oleh Abudayyah ini sangat sesuai dan berlandaskan syariah Islam.

\section{Analisis Biaya dan Akuntansi Kapitalistik}

Seperti yang telah diketahui, sistem perekonomian yang mendominasi di Indonesia adalah sistem ekonomi kapitalistik. Terdapat banyak perusahaan sebagai penggerak aktivitas perekonomian negara yang berkiblat pada ekonomi kapitalistik, termasuk juga korporasi konstruksi. Revrisond Baswir menggambarkan posisi laporan pendapatan dari suatu perusahaan yang berlandaskan akuntansi kapitalistik. Baswir menambahkan pula dengan analisis contoh laporan keuangan akuntansi kapitalistik tersebut bahwa buruh hanyalah faktor produksi. Padahal, keberadaan buruh sangat menentukan posisi laba atau rugi perusahaan, namun yang terjadi adalah sebaliknya, upah buruh diperlakukan sebagai biaya dan dikelompokkan bersama-sama dengan akun-akun harga pokok produksi lainnya ${ }^{13}$. Buruh setara dengan sumber daya, teknologi, dan modal, sehingga terdapat kecenderungan untuk berpihak kepada pemilik modal perusahaan, dan akan menimbulkan konflik antara buruh dengan pemilik modal. Apabila upah buruh dinaikkan, laba pasti berkurang. Sebaliknya, bila laba hendak dinaikkan, maka upah buruh ditekan. Karena itulah, konsep kapitalistik ini selalu menimbulkan konflik yang berkepanjangan, dan tidak menemukan penyelesaian secara adil.

Di dalam konsepsi Islam, kepentingan pengusaha dengan karyawan itu setara dan tidak bertolak belakang. Ketidaksetaraan derajat antara pemimpin dan karyawan hanya terjadi pada ekonomi kapitalistik dan sosialis, sebagaimana Rasulullah saw mengingatkan di dalam sebuah hadits bahwa pelayan kita adalah saudara kita ${ }^{14}$. Iman Soeharto dalam bukunya yang berjudul, "Manajemen Projek: Dari Konseptual Sampai Operasional", menyatakan bahwa analisis dan akuntansi projek ditentukan oleh organisasi yang kokoh dan solid, analisis dan akuntansi tersebut dibuat dan dilaksanakan harus bersama-sama secara tim yang terdiri dari beberapa orang yang solid dalam bekerja sama ${ }^{15}$. Pendapat Iman tersebut memiliki kesamaan dengan pandangan Islam. Tim yang solid adalah tim yang menganggap 
anggota-anggotanya sebagai sebuah keluarga dan pekerjaan dilaksanakan secara berjamaah, sebagaimana firman Allah swt di dalam surat AshShaft ayat 4 yang berbunyi sebagai berikut:

"Sesungguhnya Allah menyukai orang-orang yang berperang di jalan-Nya dalam barisan yang teratur seakan-akan mereka seperti suatu bangunan yang kokoh". ${ }^{16}$

\section{Analisis SNI Berakar dari Bow}

Dalam pengelolaan projek konstruksi yang sangat berperan dan berpengaruh sangat penting adalah penyusunan dan perancangan anggaran biaya. RAB (Rancangan Anggaran Biaya) menentukan laju peredaran uang yang terjadi dalam projek konstruksi. Salah satu parameter tangguhnya sistem pengelolaan projek konstruksi ditentukan oleh kepiawaian pihak korporasi dalam menyusun RABnya. Model RAB yang banyak diterapkan di Indonesia adalah model analisis BOW (Burgerlijke Openbare Werken). Model ini hingga saat ini masih banyak digunakan oleh para praktisi konstruksi kelas menengah ke bawah, bahkan perusahaan besar pun juga masih banyak yang menerapkan model BOW ini. Analisis SNI yang menjadi acuan dan peraturan di Indonesia saat ini ternyata juga merupakan pengembangan dari analisis BOW. Analisis BOW pertama kali dibuat dan diterapkan oleh pengusahapengusaha konstruksi swasta Belanda, yang akhirnya ditetapkan sebagai model analisis biaya resmi oleh Pemerintah Kolonial Belanda pada tahun 1921. BOW sudah menjadi standar yang ditetapkan oleh pengusaha konstruksi pada masa itu, terutama untuk projek-projek bangunan air atau saluran irigasi.

Sebelum BOW dikembangkan, selama masa pemerintahan Belanda di Indonesia, analisis hanya ditekankan pada biaya material, dan tidak terdapat proporsi untuk upah tenaga kerja. Pekerja yang bekerja pada saat itu adalah orang pribumi dengan sistem kerja paksa dan tidak diberi upah. Namun, semenjak digulirkannya "Politik Balas Budi" Pemerintah Belanda, maka berbagai pihak mulai menganggap perlunya diberikan proporsi upah untuk orang pribumi yang bekerja. Walaupun sudah ada proporsi upah untuk buruh pribumi, namun upah tersebut masih jauh dari tingkat kelayakan dan kesejahteraan, apalagi dengan beban kerja yang sedemikian beratnya.

Analisis BOW terus dikembangkan hingga masa kemerdekaan. Analisis BOW versi saat ini sudah memasukkan koefesien untuk tenaga kerja manusia. Walaupun begitu, dalam metode pelaksanaan projek yang modern saat ini, analisis BOW sudah tidak sesuai lagi diterapkan pada analisis biaya konstruksi, terutama untuk projek skala besar yang sudah menggunakan peralatan modern dalam pelaksanaannya. Namun, projek-projek konstruksi berskala kecil masih banyak yang menerapkannya.

Analisis biaya SNI yang menjadi acuan di Indonesia saat ini merupakan pengembangan dari analisis BOW. Saat ini juga telah marak metode analisis biaya modern yang merupakan pengembangan dari beberapa metode yang disesuaikan dengan kondisi terkini. Analisis perkiraan biaya dengan modern ini lebih teliti dalam penentuan efisiensi dan produktivitas tenaga kerja.

\section{Analisis Biaya Konstruksi Syariah}

Dari dua metode analisis perhitungan di atas terlihat bahwa kedua metode ini memiliki kesamaan dengan analisis dan pembukuan yang menganut paham kapitalistik. Menurut konsep ekonomi syariah, terdapat beberapa aspek yang perlu ditinjau dari dua metode tersebut. Pertama, tenaga kerja dimasukkan dalam item biaya langsung projek untuk produksi, berarti tenaga kerja manusia dianggap sebagai peralatan atau mesin yang berproduksi. Kedua, adanya biaya tak terduga, kontingensi, atau overhead, yang tidak dapat diperkirakan secara pasti namun dengan mutlak dibuat nilai prosentasenya, hal ini rawan termasuk ke dalam riba. Riba di dalam Islam sangat jelas dilarang, sebagaimana firman Allah swt di dalam QS. Ali Imron ayat 130 yang berbunyi sebagai berikut:

"Hai orang-orang yang beriman, janganlah kamu memakan riba dengan berlipat ganda dan bertakwalah kamu kepada Allah supaya kamu mendapat keberuntungan". ${ }^{17}$

Pada kenyataannya, para kontraktor banyak melakukan manipulasi pada biaya yang tidak pasti ini, dengan maksud untuk mendapatkan banyak laba. Tinjauan yang ketiga dari dua metode tersebut adalah tidak mengaitkan seluruh item analisis biaya dengan kualitas yang didapatkan selama proses pelaksanaan konstruksi, sehingga hak konsumen (owner) terabaikan. Dari metode SNI, pada bagian akhir analisis dibuat Kurva $\mathrm{S}$ untuk memantau progres kecepatan projek. Contoh kurva $\mathrm{S}$ ditunjukkan pada Gambar 1 di bawah.

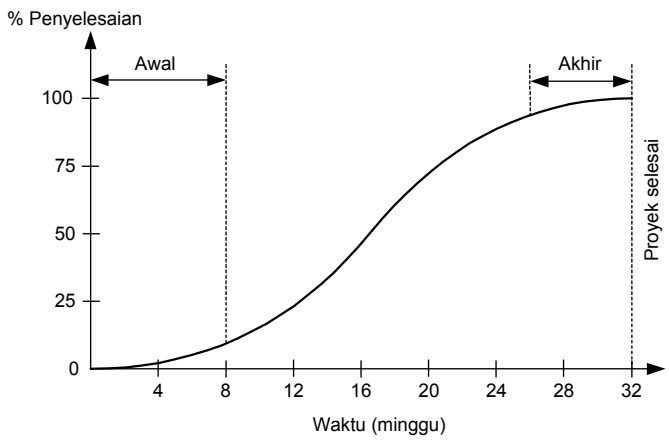

Gambar 1. Kurva S 
Manfaat Kurva S di atas adalah sebagai berikut:

1. Untuk perkiraan besarnya biaya yang harus dikeluarkan setiap periode waktu tertentu selama pelaksanaan pekerjaan

2. Sebagai alat pemantauan (monitoring) dari realisasi pelaksanaan pekerjaan, dibandingkan dengan rencananya apakah masih dalam batas normal, terlalu cepat atau terlalu lambat.

Dari Kurva S seperti ditunjukkan pada Gambar 1 sama sekali tidak menyinggung kualitas produk yang dihasilkan, dengan kata lain hak konsumen kurang diperhatikan. Padahal, hak konsumen dari pihak produsen harus ditepati dan dipenuhi sesuai dengan jalan musyawarah atau kesepakatan kedua atau beberapa pihak yang terlibat, sebagaimana dalam prinsip-prinsip manajemen syariah.

\section{Analisis Weibull untuk Memaksimalkan Laba Projek}

Analisis Weibull diklaim sebagai analisis terbaik dan paling akurat dalam perhitungan biaya di dunia, dan banyak negara telah menerapkannya, termasuk beberapa perusahaan konstruksi di Indonesia. Teori Weibull sangat sesuai untuk melakukan evaluasi performa biaya dan jadwal projek konstruksi, dan mampu menekan resiko kerugian sedemikian signifikan dan memaksimalkan keuntungan finansial. Analisis ini dilakukan dengan cara meningkatkan produktivitas tenaga kerja, sehingga tenaga kerja di berada di bawah pressure (tekanan) yang ketat dalam bekerja untuk menghasilkan progres projek yang sesuai dengan waktu atau jadwal yang direncanakan. Analisis ini sangat teliti dalam menetapkan koefisien-koefisien produktivitas tenaga kerja. Dalam analisis Weibull ini tidak disinggung kualitas fisik yang diciptakan, hanya progres yang sesuai dengan jadwal saja yang dimasukkan dalam analisis, sehingga besar kemungkinan kualitas yang dihasilkan membawa kerugian bagi pihak owner. Padahal, di dalam manajemen syariah, pihak konsumen mendapat pelayanan yang sesuai dengan apa mereka bayarkan, dan mendapatkan kompensasi atau ganti rugi apabila barang yang diterima tidak sesuai atau mengalami kerusakan ${ }^{18}$.

\section{Penutup}

Analisis biaya dan keuangan projek konstruksi banyak menerapkan paham kapitalistik. Paham ini dikembangkan oleh negara-negara Barat yang hanya bertujuan untuk mendapatkan laba finansial sebesarbesarnya, tanpa harus memperhatikan kemaslahatan pihak lain. Metode kapitalistik ini jelas akan membawa dampak kerugian bagi masyarakat di luar pihak pengusaha atau pemilik modal. Analisis yang banyak diterapkan oleh para praktisi bahkan para akademisi di Indonesia juga banyak yang menerapkan dan mengajarkan konsep analisis kapitalistik, termasuk analisis SNI yang menjadi acuan dan ketetapan di negara ini.

Sebaliknya, manajemen konstruksi syariah sangat memperhatikan nilai-nilai hubungan manusia dengan manusia, lingkungan, dan Allah swt. Keputusan dalam projek konstruksi dibuat dengan seadil-adilnya oleh beberapa pihak yang terlibat di dalam projek, antara lain pihak pelaksana (pengusaha konstruksi), tenaga kerja, konsumen (owner), dan lingkungan sekitar, dengan menghindarkan diri dari tindakan yang membawa kerugian terhadap orang lain dan kerusakan lingkungan. Prinsip ini jauh berbeda dengan metode kapitalistik, dimana segala cara dan daya diterapkan asal tujuan tercapai, keuntungan maksimal di dapatkan, tanpa memperhatikan upaya tersebut merugikan atau merusak lingkungan sekitar, dan tidak mendapat ridha Allah swt. Beratnya tantangan untuk dapat menerapkan konsep syariah dalam manajemen projek konstruksi ini menyebabkan diperlukannya empat sikap oleh para pelaku konstruksi, yaitu mujahadah (sungguh-sungguh), istimrar (terus-menerus), memperbaiki diri, dan menggalang kerja berjamaah.

\section{Referensi}

1 Iman Soeharto. 2001. Manajemen Projek Jilid 2: Dari Konseptual Sampai Operasional. Jakarta: Erlangga. h. 152

2,3 Didin Hafidhuddin \& Hendri Tanjung. 2005. Manajemen Syariah dalam Praktik. Jakarta: Gema Insani

4 Muhammad. 2005. Pengantar Akuntansi Syariah. Jakarta: Salemba Empat. h. 8

5 Muhammad. 2005. Pengantar Akuntansi Syariah. Jakarta: Salemba Empat. h. 21

6,18 Didin Hafidhuddin \& Hendri Tanjung. 2005. Manajemen Syariah dalam Praktik. Jakarta: Gema Insani. h. 95

7 Suhrawardi K. Lubis. 2000. Hukum Ekonomi Islam. Jakarta: Sinar Grafika. h. 154

8 Yayasan Penyelenggara Penerjemah al-Qur'an. 2005. Mushaf al-Qur'an Terjemah. Surat 16: 90. Jakarta: Penerbit Al-Huda

9 Ahmad Azhar Basyir. 1993. Refleksi atas Persoalan Keislaman. Bandung: Mizan. h. 194

10 Muhammad Nejatullah Siddiqi. 1991. Kegiatan Ekonomi dalam Islam. Jakarta: Bumi Aksara. h. 13

11 O.Y. Abudayyah. 1991. Cost and Schedule Control Integration: Issues and Needs. Journal Construction Engineering Management. ASCE

12 Younsoo Jung \& Seunghee Kang. 2007. Knowledge-Based Standard Progress Measurement for Integrated and Scheduled Performance Control. Journal of Construction Engineering and Management. ASCE 
13 Muhammad Nejatullah Siddiqi. 1991. Kegiatan Ekonomi dalam Islam. Jakarta: Bumi Aksara. h. 87

14 Ahmad Ibrahim Abusinn. 2008. Manajemen Syariah: Sebuah Kajian Historis dan Kontemporer. Jakarta: Raja Grafindo

15 Iman Soeharto. 2001. Manajemen Projek Jilid 2: Dari Konseptual Sampai Operasional. Jakarta: Erlangga. h. 155

16 Yayasan Penyelenggara Penerjemah al-Qur'an. 2005. Mushaf al-Qur'an Terjemah. Surat 61: 4. Jakarta: Penerbit Al-Huda

17 Yayasan Penyelenggara Penerjemah al-Qur'an. 2005. Mushaf al-Qur'an Terjemah. Surat 3: 130. Jakarta: Penerbit Al-Huda 